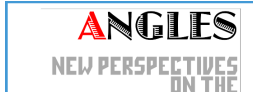
ANELOPHONE WORLD

\section{Angles}

New Perspectives on the Anglophone World

2| 2016

New Approaches to the Body

\title{
Broke House by the Big Art Group: Queer Transgressions on the Contemporary New York Stage
}

Xavier Lemoine

\section{(2) OpenEdition}

Journals

Electronic version

URL: https://journals.openedition.org/angles/1910

DOI: 10.4000/angles.1910

ISSN: 2274-2042

Publisher

Société des Anglicistes de l'Enseignement Supérieur

\section{Electronic reference}

Xavier Lemoine, "Broke House by the Big Art Group: Queer Transgressions on the Contemporary New York Stage", Angles [Online], 2 | 2016, Online since 01 April 2016, connection on 06 June 2022. URL: http://journals.openedition.org/angles/1910 ; DOl: https://doi.org/10.4000/angles. 1910

This text was automatically generated on 6 June 2022.

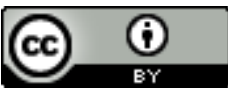

Angles est mise à disposition selon les termes de la Licence Creative Commons Attribution 4.0 International. 


\section{Broke House by the Big Art Group: Queer Transgressions on the Contemporary New York Stage}

\section{Xavier Lemoine}

Figure 1. Heather Litteer in Broke House

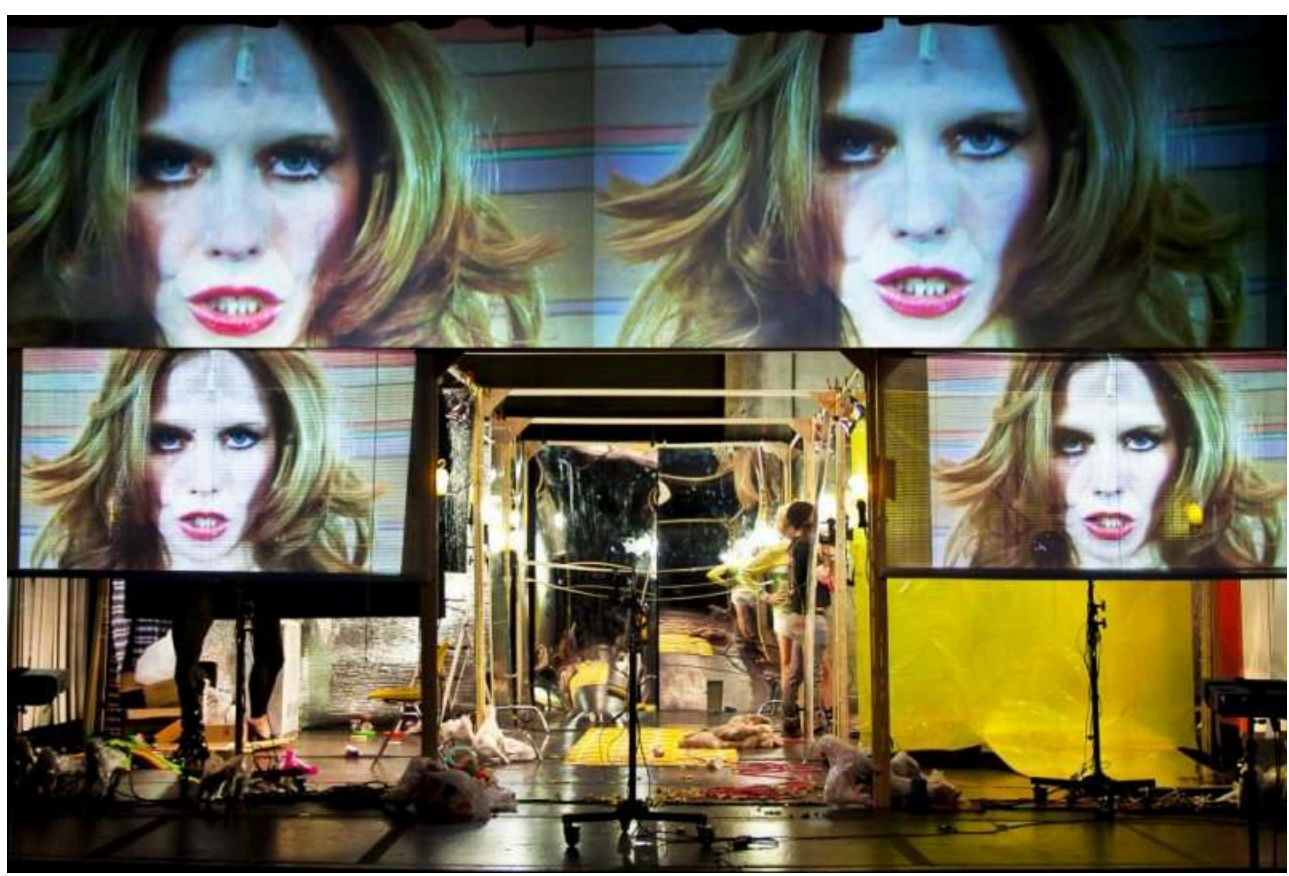

Photo by Ves Pitts. Source: http://bigartgroup.com/work/broke-house/

Queer performances explore how transgressive bodies rearticulate gender, sexual, racial and social norms of representation into complex subjectivities especially through the issue of the mediatization of the body. The Big Art Group deploys this queer art by deconstructing theater and questioning mimetic forces as they unfold in the time and 
space of a play. Broke House, performed at the Abrons Arts Center in the Lower East Side in New York City in January and April 2012, staged the theatrical body through cyber performance. This piece relies on technological and theatrical effects that blur the lines defining the normative body and rework the codes of representation. As in most of their previous shows, Jemma Nelson and Caden Manson, the creative couple of the Big Art Group, intertwined two main plots establishing narratives designed to structure a chaotic world that gradually collapses with a view to reaching a new perception of spaces, stories, and bodies. Indeed, by turning to Chekhov's Three Sisters, the artists take on the self-destructive Russian family, realism, and its bodily constraints not so much to liberate the subject but to probe into contemporary norms and show they are as demanding as regards the performance of a coherent body. The second plot elaborates on a zany mythical world where semi-gods fight and love each other in Day-Glo colors. These fictional worlds create the opportunity for the audience to experiment with fluid identifications and disidentifications. Yet, failed representations and identifications would describe more accurately the transgressive intent and esthetics of Broke House.

2 Grappling with normative forces, such as theatrical realism or heteronormativity, the artists display a queer perspective through fantasized, campy, and distorted embodiments. The artists partake of the experimental New York performance art scene by combining multimedia and queer theater. ${ }^{1}$ Bending theater and performance, they break down the bodily limits of realism through cams and screens, glam and sci-fi. We can wonder, then, to what extent the Big Art Group manages to point at the unstable nature of the body through queer subjectivities and technological performances.

3 By looking at the composition of the performance, especially the plots and the multifarious stage design, we can unpack how the Big Art Group tries to transgress theatrical and bodily codes through a subversion of mimetic representation. Their queer camp style generates variations of failed embodiments and interpretations that change the traditional norms of corporeal productions.

\section{Bodily Transgressions}

Broke House sets up modes of transgressions based on the establishment of distinct perimeters the limits of which can be transgressed, blurred, and redefined. This is made possible by the practice of a theatrical performance that relies on a game involving narrative and representational codes. The Big Art Group can be understood as developing what Josette Féral (2011) called "performative theater". ${ }^{2}$ Performative theater deals primarily with presentational acting while not denying the production of meaning and interpretations. The clash between mere corporeal presence and symbolic embodiment is articulated in Broke House. That's why Broke House questions mimetic representation and representational codes. Indeed, magnified mimesis and bodily distortions come to disturb conventional acting and realistic embodiments of plots and characters.

\section{Film in Theater. Mimetic Blur}

5 The general structure of the piece first displays an identifiable narrative pattern even though borrowing from postmodern principles such as hybridity, fragmentation, and non-linearity. Broke House develops two main plots that frame the bodies on stage 
within a recognizable theatrical tradition. Simply put, the first narrative is based on Chekhov's Three Sisters and the second one is a mock sci-fiction webfilm. As is common with the Big Art Group (Gallagher-Ross 2010), ${ }^{3}$ both plots become increasingly intertwined to the point of disintegration, disorder, and final chaos. First, Three Sisters was used as a basis for improvisational work that led to the writing of a new script. In this rehearsal phase, the troupe also worked with a 1975 film documentary, Gray Gardens dealing with a mother and daughter living in a decaying mansion. From these sources resulted the first hybrid plot that brought together a sister and a brother who are pursuing unrealistic goals in an inherited house they can no longer pay for. Manny (David Commander) and his sister Irena (Heather Litteer) invite documentarist Dave (Edward Stresen-Reuter), to film their work on their sci-fi webfilm (see Figure 2).

Figure 2: Manny and Irena invite Dave to film their work

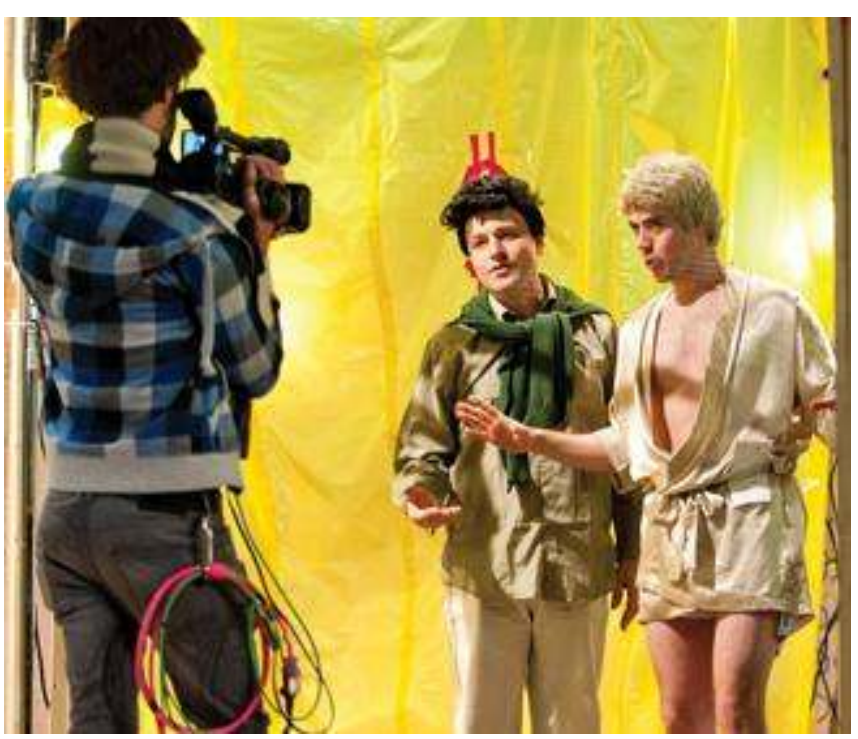

Pictured: David Commander, Matthew Nesser, Edward Stresen-Reuter.

Photo by lan Douglas. Source: http://sfbgarchive.48hills.org/sfbgarchive/2012/01/17/way-out-east/

Mocking the trend of reality TV, the intruder quickly prefers to focus on their private life, including their assistant and two drag queens, and the foreclosure of their house rather than on their art work. As spectators, we get to see snippets of this webfilm that turns out to be fully staged moments in the performance, thus providing a second main plot. This sci-fi plot is performed in dark light with the same actors performing with masks sprayed with fluorescent paint (Day-Glo). As a result, the audience enjoys a double plot with two clear illusory theatrical spaces performed on the exact same stage and magnified on the same screens above it (see Figure 3). There is an undeniable pleasure in the mastery of the performers to conjure up these worlds and to play with such physical transformations. However, this device might, above all, serve as a metanarrative reflection on how theatrical representations mix with performance art and alter the perception of the body on stage. As performance studies professor Peggy Phelan pointed out: "Performance and theatre make manifest something both more than and less than "the body." (Phelan 3). Here, the back and forth between plots, universes, and registers of presence (stage and video) redefine the ontological perception of the body. 
Figure 3: Magnifying screens

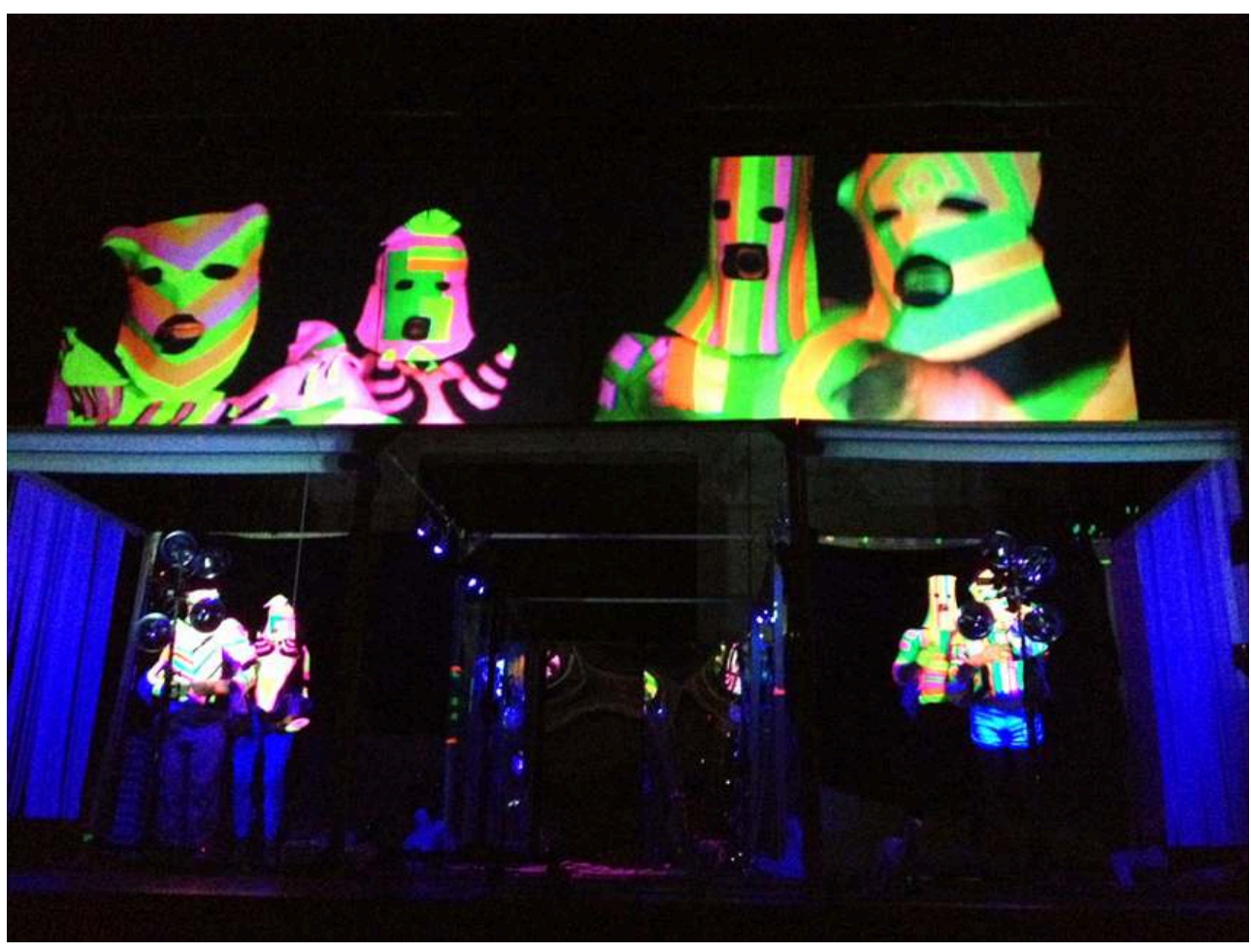

Source: http://spankartmag.com/archives/10467 [not archived]

7 First, they borrow from the well-known meta-theatrical device famously staged in Shakespeare's Hamlet of the "play-within-the-play." Here, it becomes a kind of "film within a play" but, unlike the Wooster Group's Hamlet (Callens 2009; Lemoine 2008) that based its acting on a cinema version of the play, the Big Art Group directly theatricalizes film techniques which produce simultaneously a performance on stage and on screen. Within the first plot, we see on the large screens above the stage, the (live) footage of the making of a documentary film of a "making of" of the webfilm that we see performed both on stage and on screen. The images on screen are mainly the result of the acting on stage, despite some pre-recorded images. Beyond the many parodic effects, this scenographic design could be understood as an attempt to capture the contemporary mechanisms of performance whereby self-reflections are offering a way of questioning codes of representations and interpretations while producing them. It questions the meaning of images in the hypermediatized world and the role of the body in that process. This staging makes clear that our bodies are determined by their relationship with the mediatized - or at the very least cannot escape it. As the actors perform both for the audience and for the cameras, including those of the fictional filmmaker, they multiply the levels of fiction - maybe to the point of exhaustiveness. This raises the question as to whether multimedia acting alters the quality of the body. It also highlights the issue of stage and film editing, that is to say, the very construction of knowledge: how do the stage director and the filmmaker select their frames and angles, which, in turn, produce specific conditions to decipher the body? Can the acting body resist this epistemological framing? How are we, the audience, ever sure about the origins of those images? And, as a result, how are we to understand our own bodies their origins, their meanings? 
This interrogative process is what Broke House stages. Initially, the clear separation between the two plots helps show how different types of illusions work, and especially how narratives are used to invent fictional spaces. During that phase, both spaces seem to have very different visual codes, almost based on binary oppositions. Abrupt changes of lighting make the point: the sci-fi film is unfolding in the dark, while the Three Sisters plot is bathed in crude lighting. It is literally day and night, reality and fiction. The bright light of the makeshift house sharply contrasts with the dark light used to make Day-Glo Bauhaus-like costumes stand out. But gradually the illusion of clear-cut worlds supported by radically different bodies (overexposed fleshy ones as opposed to underexposed hidden ones) crumbles. The makeshift mythical costumes of the sci-fi movie start to fall off as underexposed bodies become visible while the overexposed bodies of the family home are crowded by objects.

This keeps narrowing the gaps between the fictional plots and the reality of the performance. Various levels of referents keep interacting, creating a dizzying sense of perception and interpretation that conjure up mimetic mechanisms only to make them stall. The vertigo of a baroque spiral feeds on the destabilized bodies that question the division between art and life. How the body incorporates the real ${ }^{4}$ to flesh out characters, and even the mere presence of the actors, is highlighted by the video devices and the screens that build up narratives both concrete and virtual.

Figure 4: Performing bodily absence

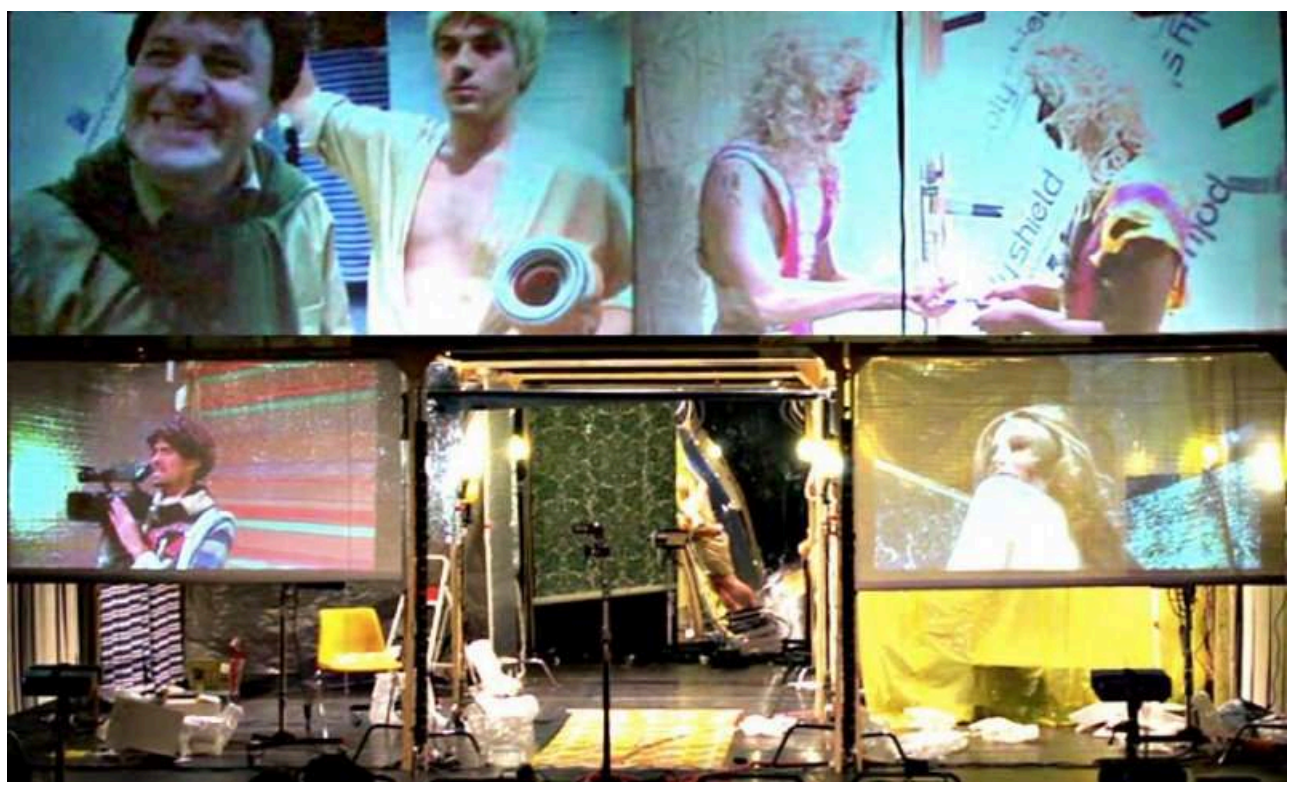

Clockwise: Edward Streser-Reuter, David Commander, Matthew Nesser, Heather Litteer.

Source: http://bigartgroup.com/work/broke-house/

\section{Blurring Spaces and Bodies}

Right from the beginning, both spaces encroach on each other through narrative and staging. After all, the filmmaker mediated between the two worlds from the start, since he came to Irena and Manny's house to document how their sci-fi folly was created. As Dave's project collapses, turning his camera on the family home (since he wants to know more about Irena and Manny's private lives), the war taking place in the Day-Glo 
world becomes a reflection of the tensions in the house. By the end of the play, the skeleton house is literally taken apart, while the illusory division between the two spaces is abandoned to show how deeply both worlds are enmeshed. What is at stake is the effort to erode the mimetic mechanisms, to extenuate the illusion not only of fictitious worlds but also of real ones. As in the end of Dead Set ("Void" 2007), the Big Art Group creates a nihilistic final image as the house is turned into a huge pile of waste which is then taped together to form a gigantic ball, a small planet of debris. The final props of illusion are discarded. Similarly, the sci-fi battle spills over into the audience when red and green laser beams flash through the auditorium putting an end to the realistic theatrical frame sealed in the black box theater.

Figure 5: Heather Litteer, Matthew Nesser, Edward, Edward Stresen-Reuter

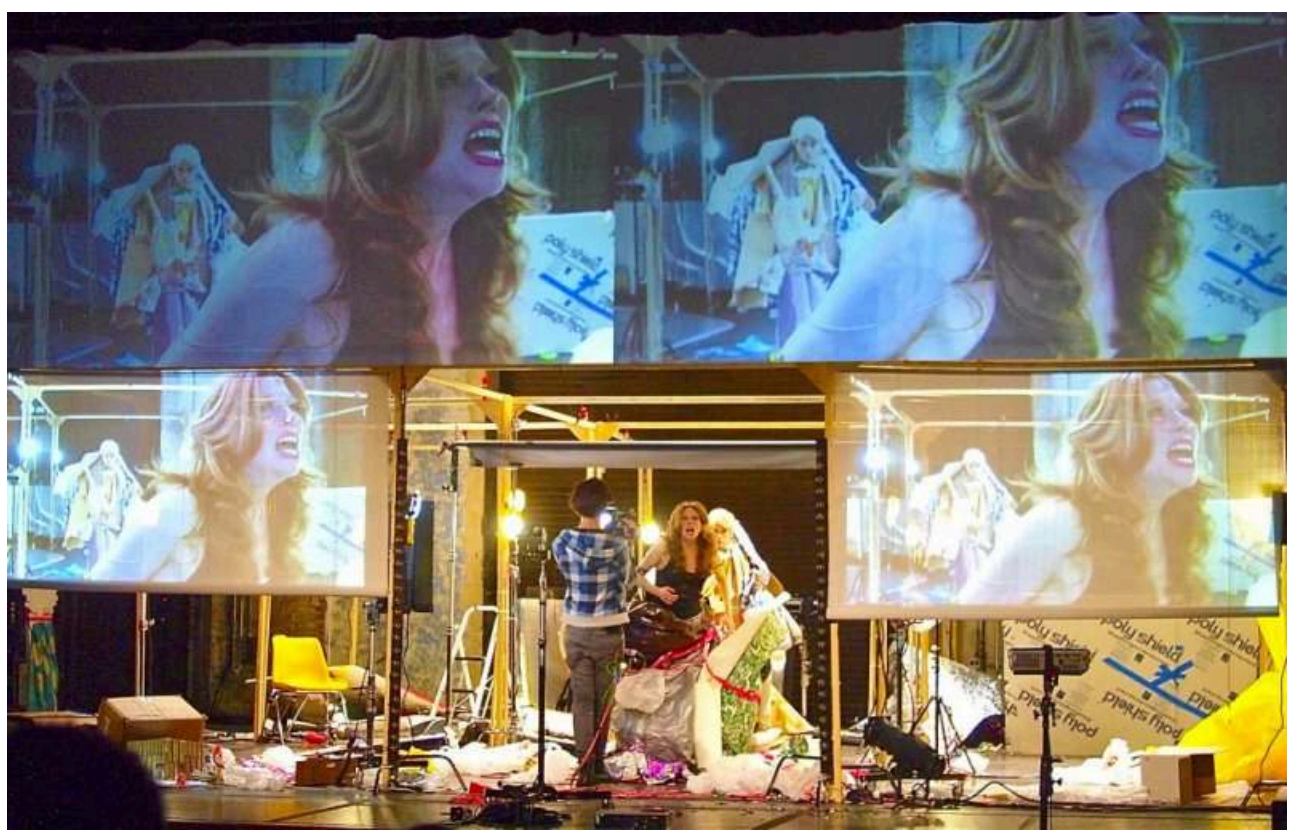

Photo by Big Art Group. Source: http://bigartgroup.com/work/broke-house/)

11 The end is only part of a process that can be witnessed throughout the play which aims at breaking down walls between various fields of representation. The theatrical action mixes with the cinematic one. The fact that the screens themselves, placed above the stage, are architecturally serving as proscenium reveals as much. The screens also suggest how the distinct fictional spaces in the play are always already blurred by the fact that they are displayed on those same screens from the beginning. Ultimately, this signals the impossibility of the binary logic that pretends to produce a knowable essentialized body. The instability of the autonomy of the spaces, foregrounded by this tension between screen and stage, questions our perceptions. At best, then, there is an epistemological exploration of how this articulation captures the imaginary processes through a dematerialized corporeality. At the same time, it signals how corporeality is co-extensive with its environment echoing the phenomenological apprehension of the body. As Anna P. Foultier, a Swedish philosopher who analyzes the dancing body, puts it to explain Merleau-Ponty's definition of the body:

the body-proper is not given once and for all, as the sum of a range of organs attached to one another and animated, but is instead a meaningful unity, whose 
significations are dependent on a natural, cultural as well as personal situation.

(Foultier 67) perception can be obtained. This effort to produce a reflection on our perception of the body as it is defined by ontological questions (desire, gender) but also structural ones (technology) is at the heart of Broke House.

Figure 6: Broke House, Jan. 2012

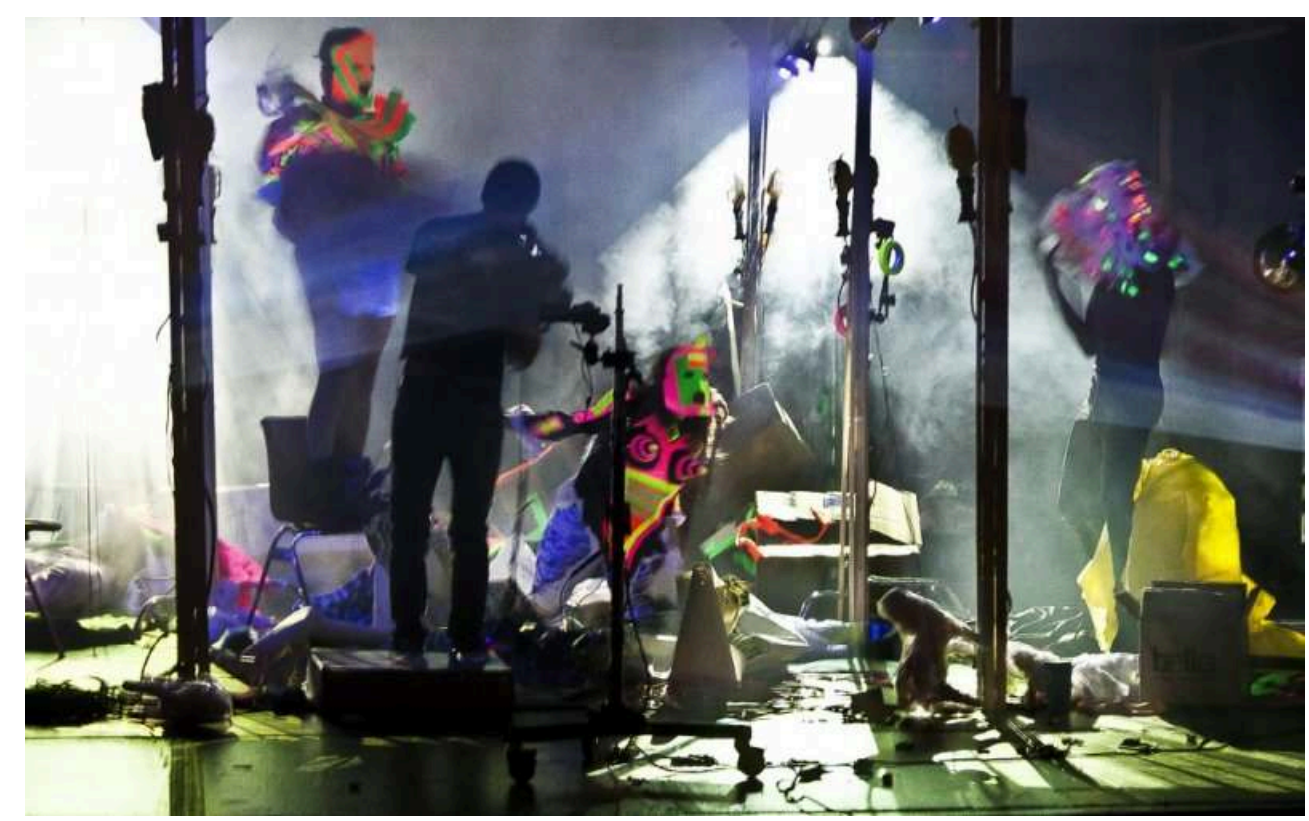

Pictured: Willie Mullins, Matthew Nasser, and Edward Stresen-Reuter.

Photo by Ves Pitts. Source: http://bigartgroup.com/work/broke-house/)

By pitting the actor's body against the screens, the play strives to show how bodies are affected by contemporary technology. Which is more real: the acting body hampered by obstacles of all kinds (thin walls, cameras on tripods, spotlights, etc.) on stage? Or its image on screen? The answer might lie in the secrecy of each spectator's reception, but what is clear is that such interrogation cannot be shunned by audience nor performers. The Big Art Group does not seek to erase the live body while working at debunking basic binary oppositions such as between live and mediatized. As Jemma Nelson makes clear:

I think the challenge for us, having worked with technology for a while, is how to keep it organic. Keeping the focus on live and what is live, and what is that livenessfeeling. (Barker 2012)

14 As the body becomes mediatized, it exists in a double register of presence/absence. It relies on the immediacy of performance but also on the mimetic devices of abstraction - the cinematic body appears to stand for the absent live body. The tension between the two is theatricalized, as we can see the original body on stage being turned into a dematerialized image. The process of erasure of the carnal body is shown in various ways; or, rather, the coexistence of these two bodily expressions is turned into a performance. Hence, bodies are shaped by contemporary technologies. Yet, the power of technology is not to be radically opposed to liveness, as performance scholar Philip Auslander explained in his book Liveness, theater and technology have become 
intrinsically linked: "As the mediatized replaces the live within cultural economy, the live itself incorporates the mediatized, technologically and epistemologically." (Auslander 1999: 39) This is what the confrontation of the live and the digitalized body(ies) create in Broke House. It is simultaneously a singular and plural body - the same body and, at least, two different bodies. This complex corporeality results from the technological environment, but is connected to the continuous process of embodiment. After all, in Broke House the material is destroyed, the house falls apart, not merely as a nihilistic gesture but also to better determine what kind of new house needs to be rebuilt and how to redefine the bodies that can inhabit it. Interestingly, these interrogations echo Chekhov's critical view of an agonizing Russian bourgeoisie in Three Sisters soon to be destroyed by the Bolshevik Revolution. Yet, the Big Art Group offers more questions than answers which directly address the contemporary audiences who are heavily plunged into the growing omnipresence of technology. The ubiquitous use of smartphones, including in theaters, highlights an inescapable link between what is happening on and off stage. The audience, then, is involved in the shows' production to the extent that they keep manipulating their environment and bodies with identical technologies, through selfies, tweets and global chatting, thus collaborating to the construction of meaning (or lack of) between the production and the reception of the play.

In the end, the actors' bodies do not dissolve in their images. The back-and-forth between an anthropophagous image and the bodies they feed on creates the unstable performance. The contemporary bodies grow and live through such tensions, yielding energy and destruction. The actors must disappear to reappear in imaginary constructions and be reconfigured in terms of fluidity, openness, and co-creation or "inter-corporeality." It is a quest to describe the individual's body but also the social body. Indeed, the bodily crisis was not disconnected from the US social crisis at the time of production as made clear by the show's program:

Beyond the topical symptoms of foreclosure crises, credit crises, occupy movements and extremist rhetoric, we suppose that the metaphorical heart of the country has been suffering, and perhaps has decided to rebuild the body that surrounds it. ${ }^{6}$

In Broke House, everything crumbles and the walls of the house are torn apart like the relationships among the performers. Yet screens and new relations might rebuild bodies and try to address a social reconstruction through the potential interpretations of the audience. The questions remain nonetheless whether it is a Faustian pact to trade a live body for a mediatized one. Is it a path to reconstruction or destruction? Are the screens redeeming the live or condemning it? 
Figure 7: The walls of the house are torn apart

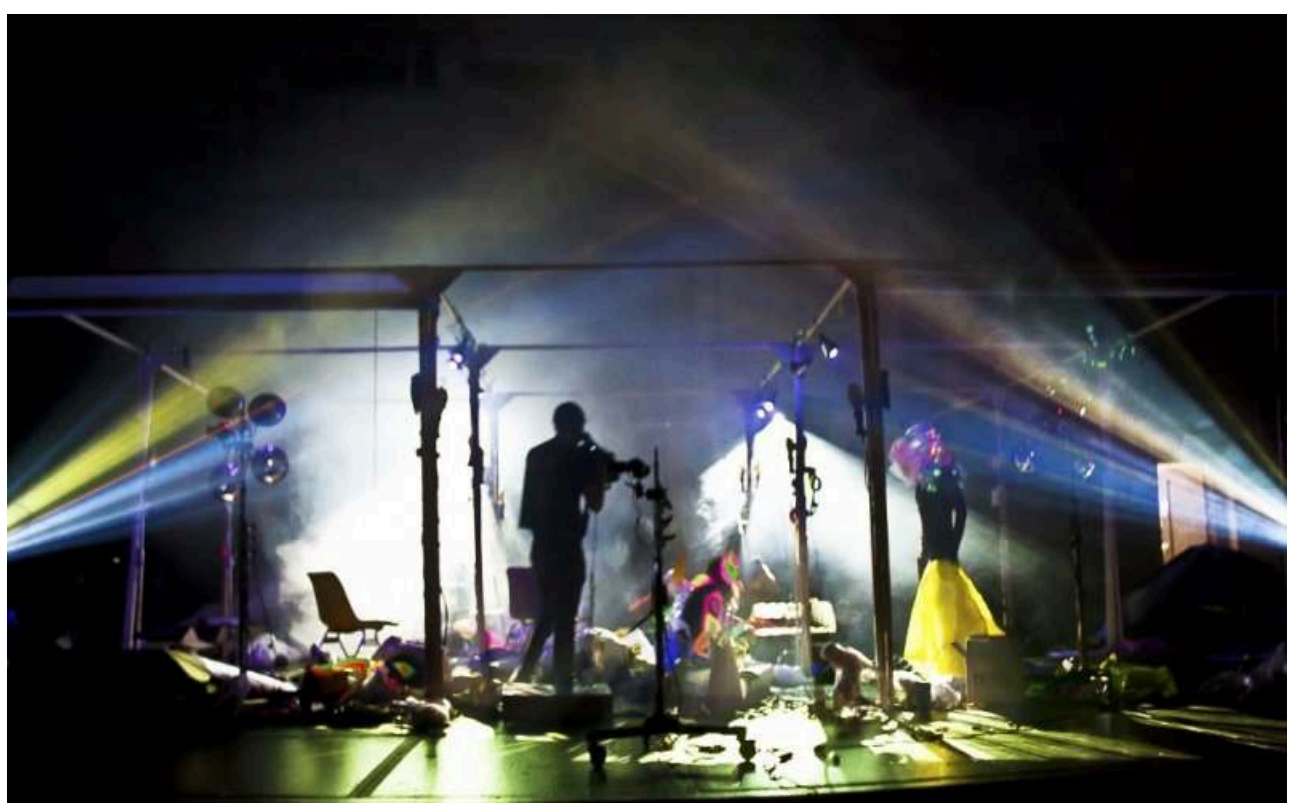

Photo by Ves Pitts. Source: http://bigartgroup.com/work/broke-house/

17 What is striking is Jemma Nelson and Caden Manson's effort to create a network of layers not only based on the stage design but also reflected in their acting method based on a theory of spaces. ${ }^{7}$ As mentioned earlier, they mix references and have improvisational sessions with the actors and the technology from the start:

When we say rehearse and improv and stuff like that, it's with all the gear from the get-go, from the beginning. All the language is being developed at the same time. (Barker)

The bodies are embroiled in classical theatrical references (Three Sisters), cinematic influences (such as the documentary Gray Gardens), site-specific art by Gordon MattaClark (Manson and Nelson, 2015), ${ }^{8}$ and queer performance artist Jack Smith (Rothkin 2012). Furthermore, as the artists explain, there is a sense of fluidity that emerges from their constant editing:

"A lot of it is exploring the inability to cope, and a constant kind of breakdown. So we built it on trying to remember things. The script was first improvised for about four weeks, and then we've taken that - I edited it then Jemma started to change it more."

"Doctored it," Nelson corrected.

"Doctored it!" Manson added with a sardonic chuckle. "It's very doctored now!" (Barker)

19 All this suggests a multiplicity of partial spaces which echo Merleau-Ponty's notion of the body stemming from a "polymorphous space" (quoted in Foultier 70) and vice versa. The actors' bodies co-create new spaces. A series of new worlds - on screen and on stage - keeps appearing and falling apart. In the end, it is clear that this is linked to the new status of the human body interacting with everyday technology. As Jemma explains in detail:

"Our first technology is the actors themselves," Nelson made clear, "and it's the way that we train the actors, and that's really the foundation about which all this orbits. It's interesting that people often look at us as a heavy tech company, when what we mostly try to use is consumer grade electronics and things that are 
available to everyday street users. And we're really talking about the ways we use technology every day, in which we are facile in manipulating our own images and sending our images to other people and receiving them back. So it's that language around technology, it's the use of it - that's where we're quite heavy." (Barker) sense that they explore the idea that the virtual body is not yet detached from the body itself. The ontological body creates its mediatized version, yet it is transformed by this very process. The giant faces on screen cannot exist without the real face of the actors, but maybe we cannot see the "real" face without the video. In order to grapple with these new realities and spaces the Big Art Group plays with transgressive desires which could be traced to a queer style, in the sense that they try to derail a normative body that would remain within the constraints of a mimetic representation. As Phelan suggests in generalizing and psychoanalytical terms:

As an art form whose primary function is to mediate on the threshold that heralds between-ness, theatre encourages a specific and intense cathetic response in those who define themselves as liminal tricksters, socially disenfranchised, sexually aberrant, addicted, and otherwise queerly alienated from the law of the father. (Phelan 16)

\title{
Queer Esthetics?
}

\section{Technological Camp}

Broke House, much like Big Art Group's other shows, toys with many grotesque forms of queer desires that could be expanding the tradition of camp. Barker summarizes the complex networks of queer camp desires in the plots:

\begin{abstract}
Just as they collectively mediate their own desires through the invention of imaginary worlds through low-budget web films, the main characters find their hopes and dreams mediated through various technologies. One sister, played by Heather Litteer, is somewhat comically taken in by romantic Nigerian-email scams; Matthew Nasser's perennially unpaid handyman is smitten with Litteer's character, and hopes to convince her to go into making more profitable online films (to be euphemistic about it) to get them the money to escape their perverse situation they're in; and finally David Commander, who plays Litteer's brother, longing for romantic engagement, convinces himself the documentarian's in love with him. (Barker)
\end{abstract}

This emphasis on the multiplicity of non-normative desires was at the heart of the seminal camp film Flaming Creatures (1962) by Jack Smith, as well as in his New York performances. The camp tradition was developed more specifically on the 1960s and 1970s New York stage by the Theater of the Ridiculous, and later by Charles Busch. Although the Big Art Group is not, strictly speaking, connected to the latter, they stage drag queens whose acting relies on exaggeration, and spice it up with technology. Two long-legged drag queens, one African-American, one Caucasian, appear in Broke House, hinting at the supermodel spin of camp cross-dressing, interlinking with the New York drag scene encountered in gay clubs, the Wigstock festivals, and even the mainstreaming of drag queens like Ru Paul. 
Figure 8: Camp cross-dressing in Big Art Group's Broke House

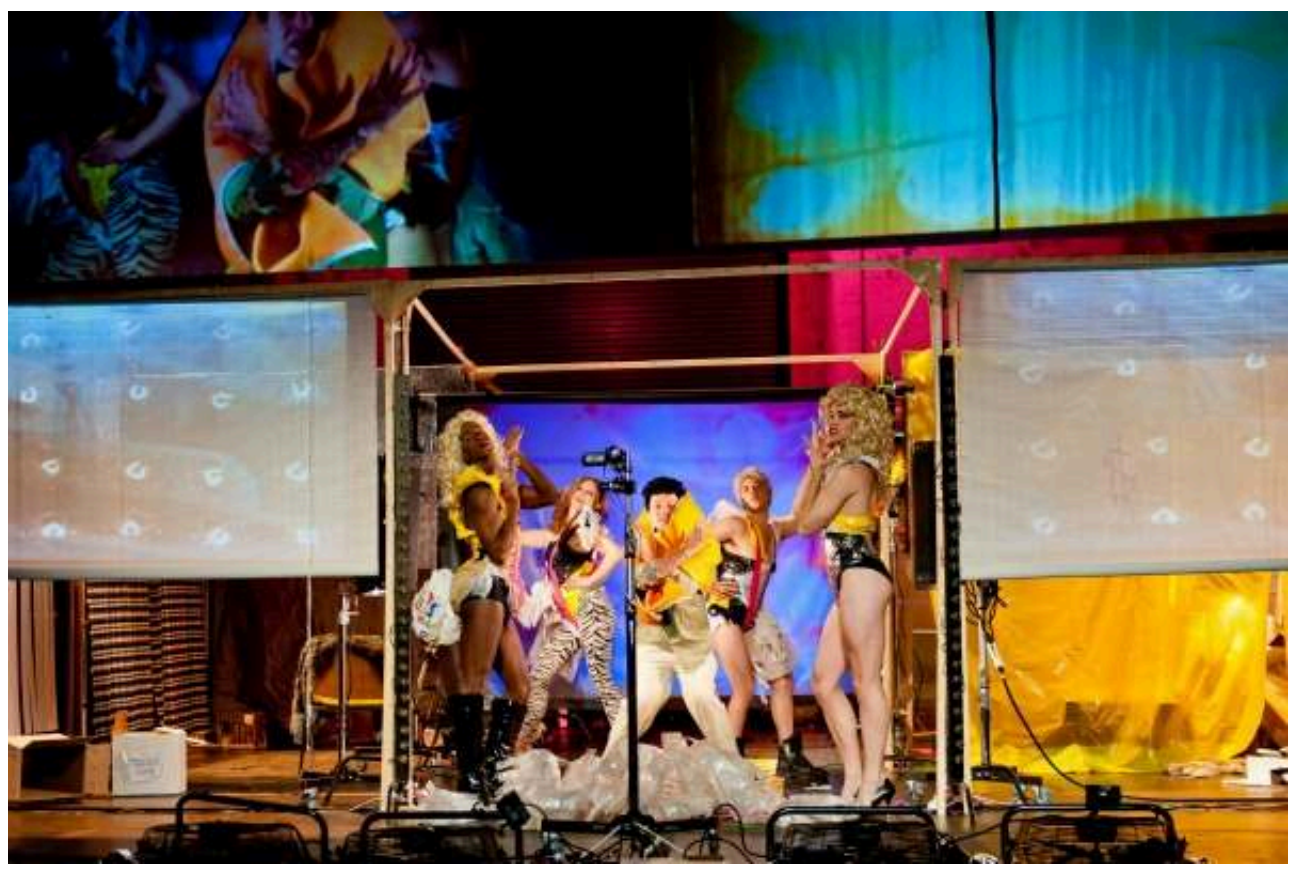

Photo: Ian Douglas. Source: http://bigartgroup.com/work/broke-house/

In the controversial "Notes on "Camp" by Susan Sontag, we can already read that "[t]he androgyne is certainly one of the great images of Camp sensibility." (Sontag 279) Cross-dressing was further explored in the anthropological study Mother Camp by Esther Newton (Newton 1972/1979) and famously theatricalized by Charles Ludlam's embodiment of Camille in a production of The Ridiculous Theatre in $1973 .{ }^{10}$ In addition to many other clues, this is why we can argue that the Big Art Group revisits the camp tradition by enrolling drag queens, asking such questions as: how does cross-dressing work with technology? Is there a new multimedia queer camp style suggesting new body politics? It seems that the power of the camera to rearrange the construction of one's body is parodied in the drag queen's inflated yearning to be filmed. These drag queens wish to enter the world of images at all cost as they ostentatiously, or should I say campily, prepare for their close-up. Thus, they reveal how bodies in general are contaminated by their desire to be filmed and are always already transformed by the promise of the camera (whether this promise is fulfilled or not.) Paradoxically, the promise of a close-up ontologizes the body of the drag queen, which is based on a drive to escape its ontological sex, or, at the very least, to denaturalize it. As Judith Butler has suggested, there is an inescapability of the body, even in the drag performance: "What is 'performed' in drag is, of course, the sign of gender, a sign that is not the same as the body that it figures, but that cannot be read without it." (Butler 237). Similarly, in Broke House all bodies on screens have a digital essence, maybe no essence at all, in the sense that by being filmed they acquire their intentional identity - a queer identity based on gender manipulations and transformations - while maintaining the relevance of the body. It is maybe thanks to their proliferating presence on stage and on screen that they fully perform their becoming drag queen, and more generally a becoming of the body. Indeed, the camp exaggeration ${ }^{11}$ of drag queens on stage becomes mediatized by the sheer size of the screens blowing up the bodies caught by the camera. This mechanism is then a suggestion of how all mediatized bodies can potentially become 
camp in the eye of the camera - at the cost of losing the stability of the norm. Indeed, this technological camping is taken up by all the characters of the Three Sister plot but also by the characters of the sci-fi fantasia where the bodies are first displaced in a world of images, as the masks they wear suggest, and are, then, displaced by the camera.

Furthermore, the sexual desires of all those characters parody the seriousness of the sexual norms that define the body as well as gender. Both brother and sister fall in love with people that they can only access through technology (the phallic power of the camera of the documentarian for Manny, and the deterritorialized phantasy of the internet for Irena). But both relationships are illusory and conspicuously impossible. The camp nature of desire triggers laughter and might highlight a call for more direct relationships or at least show the folly of sexual desires in the limiting frames of technology. The final apocalyptic destruction of the house might be a call to break down the houses of norms and end the control of spaces, be they technological or social. Camp ambivalent humor is also clear in the sci-fi skits evoking mythological gods obsessed with war and sex. As they go to war, they also experiment sexual trios creating a clash between high-minded discourses of conquest and animalistic carnal desires. This mix of high and low styles, the use of psychedelic Day-Glo effects, all conjure up a highly camp moment where a sense of beauty is mocked but, nonetheless, still raises a number of serious questions on representations, framing, and social life.

Such technological campiness addresses the transgressive queer sexuality and how it can redefine our contemporary subjectivities caught between flesh and flux. A sense of danger surfaces as we wonder whether this technology traps bodies in a selfdestructive isolation instead of unleashing productive desires and multiple connections. The ambivalence toward the effects of technology can be extended toward language and interpretation itself. Resisting any simplistic classification of their work, the Big Art Group tends to reject labels that would foreclose interpretations or eschew contextual elements. Nelson then reflects:

Lately, the use of the terms 'camp' and 'trash' aimed at our work have aligned us somewhat with Smith's legacy. But these terms are tainted or changed nowadays for 'camp' by Sontag's essay (with which I disagree totally), by renewed homophobia in the American landscape as well as political changes in queer visibility. Camp is such a contextual term, we have been thinking about creating a panel on it in New York. There seems to be a basic misunderstanding or refusal of queer politics, of queerness in performance, in NYC at this moment. (unpublished interview of the author 2015)

Although we can understand this caveat in the context of an economic crisis, it might be necessary not to throw the baby with the bathwater. The fact that the performance addresses this issue seems to inscribe contextual traces that might help us not fall prey to gross misunderstandings. On the contrary, by harnessing camp to queer and technology we might make sure we fully address such issues without impoverishing such concepts. Similarly, the notion of "trash" within the queer tradition started by Jack Smith can be understood as a significant element of the show.

\section{Camp Set}

27 The set of the house is basically an elaborate junkyard in the shape of a skeleton house. The overall effect creates a sense of beauty reminiscent of Stefan Brecht's description 
of Smith's performances under the title "The sheer beauty of junk"12 in his book Queer Theatre. In keeping with queer politics, this sense of esthetics does not suppress but, on the contrary, highlights the political consciousness of the housing crisis due to the 2008 subprime meltdown. Houses have been turned into mere disposable objects defined by a short-lived consumer cycle. Human bodies seemed to be trapped in this lethal capitalist destiny. Bodies and their images can be traded and discarded once they have served their ephemeral purpose. The staging turns everything into a wasteland, including bodies.

Figure 9: Trading bodies and their images

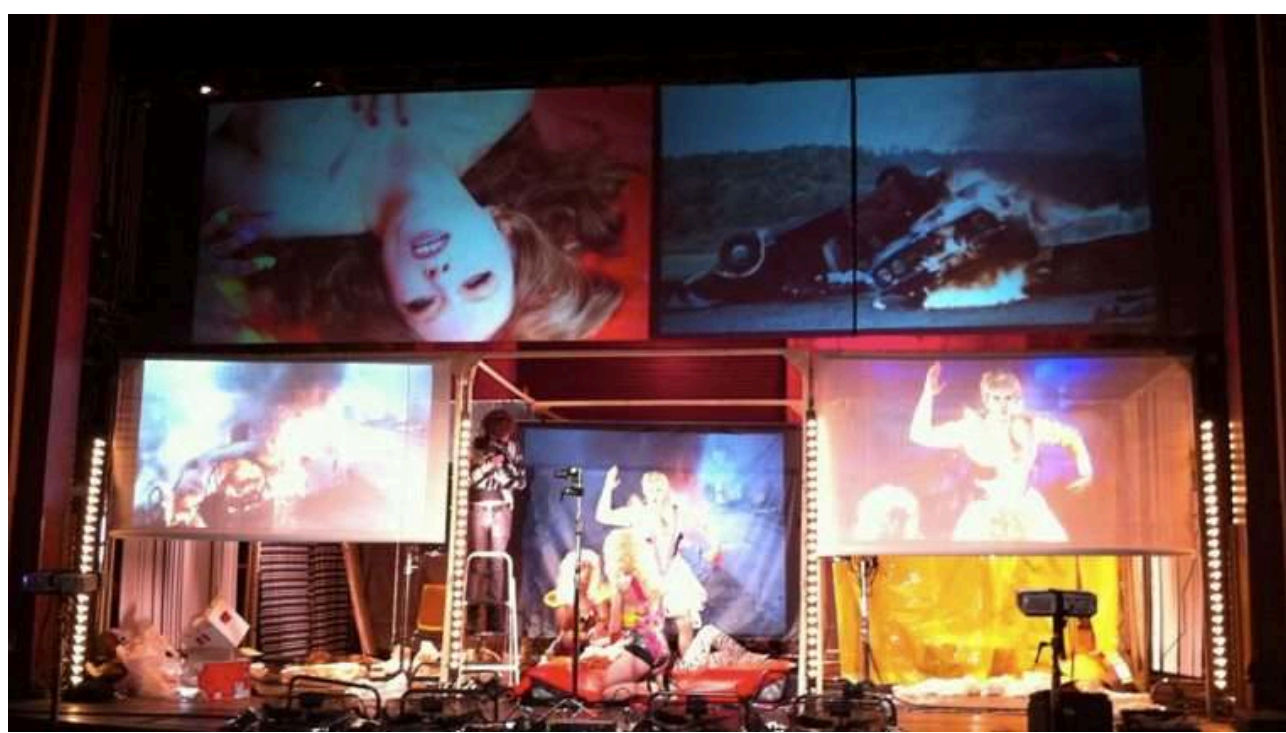

Broke House Showing, Jan. 2012

Source: http://bigartgroup.com/work/broke-house/

The set made of plastic bits, crates, scotch tape, paper walls, and plywood conveys a sense of chaos that affects the bodies. If the body is made of its relationship with its environment, the trashy objects become trashy bodies. As for the cat that Manny gives to Dave - a reminiscent prop already present in other Big Art Group performances, the animals are turned into plastic. By the end of the play, the bodies are altered as the siblings lose their house because of the mortgage and symbolic foreclosure. They are turned into improbable human snails carrying on their backs a giant ball of trash. This camp house is also a burden that crushes the bodies, threatening their livelihood. The body becomes a piece of trash as well, obliterating its humanity. How can one survive this catastrophe? By being marginalized, as in the process of abjection experienced in queer subjectivities - the play thus raises the question of political activism as an understanding of what queer means. ${ }^{13}$ It creates a post-apocalyptic hope for something new, a potential for re-imagining and re-appropriation close to the re-signification practice of queerness into a criticism of normative sexuality. Butler explains the reversal through a practice of citation that mobilizes the power of queerness: "This kind of citation will emerge as theatrical to the extent that it mimes and renders hyperbolic the discursive convention that it also reverses." (Butler 232) This could, after all, redefine the camp style of exaggeration by making it clearly political, moving away from Sontag and coming closer to a notion of queer camp that might better suit the Big Art Group. 
Figure 10: Economy vs. Empathy

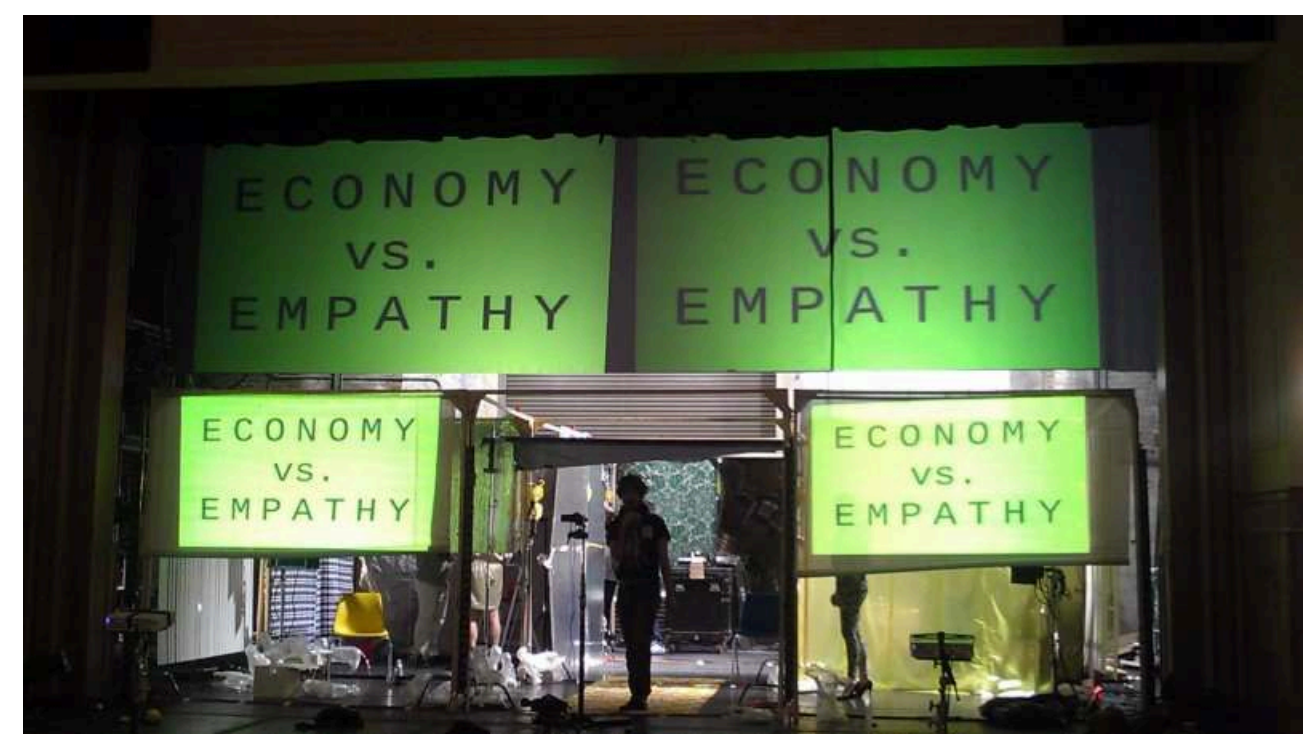

Broke House rehearsal, Jan. 2012.

Source: http://bigartgroup.com/work/broke-house/

The desire for political agency is suggested by the Brechtian images on the screens: "Economy vs Empathy," 14 but nuanced by another phrase: "The De-Realization of Politics." This might point out that there is a direct question addressed to the world of performance as defined by the logics of perspective and its vanishing point as a capitalist economy of insatiable desire through endless accumulation (Schneider 66-72). The objects on stage are thus already resisting this quality of desirable goods in the late capitalist cycle of consumption. Moreover, the set must disappear entirely so as not to fall into an overly symbolic interpretation of the performance and resist appropriation. As this set is continually (at least for the duration of the show) rebuilt and destroyed for each new performance, what matters is the process, not the final product - there is not really one, just the idea of one. Illusory acts can be fun, but they must be done away with, much like normative identifications, as they only reify the performance and the body. The Big Art Group clearly states their effort to open up spaces and deconstruct normative constructions that restrain and restrict the body into congealed images or commodification. By recycling high and low culture in a queer camp expansion, they show the powerful contradictory fluxes that run through the body and hopefully contribute to raise productive esthetic and political interrogations. They position their art on the crises that reopen economic, political, and esthetic questions to offer a de-centered or queer vision of the world.

\section{Embodied Reception/Deception}

Reception is an important part of the meaning of art, as it can help us conclude that performance today in New York City and in a computerized world is quite frail. Broke House was performed for the first time at the American Realness festival from January 5 to 15, 2012 (Avila 2012), and, then, an additional run took place in April 2012; both were in the same space in the Lower East Side. ${ }^{15}$ As space plays a part in the processes of bodily definitions, it is worth noticing that this space is historically located in what we 
could call the underground performance triangle between Soho, the East Village, and the Lower East Side. Revealingly, Smith also performed on Grand Street in the Lower East side, although not in the same exact location. This marks this area as a transgressive one which welcomes transgressive performances.

On the night I attended the show, transgression was as much on - as off - stage with an artsy audience, including queerly marked bodies. This created a uniquely congenial atmosphere where a potential for communion between the stage and the theater was to be expected and enjoyed. The strong connections between openness toward many forms of bodily appearances belied a slight discomfort, however. The theatre was half empty, to begin with. Some earlier bad reviews might have been the culprits. Nelson felt that the negative criticism was due to the critics' inability to deal with the troubling issues they touched on:

I think the 'trash' term, which recently Time Out New York attempts to use against us as a slur, is interesting - because it brings up so many issues that Americans just seem to refuse to deal with - intentional blind spots - issues about class, about economic production, injustice, environmentalism, something that really stabs at the heart of the American character. (author's unpublished interview 2015)

How can transgression become attractive to a larger audience? Conversely, can queer bodies be queered further? Can social bodies be redefined individually and willingly? Clearly, a number of New Yorkers think of these issues and enjoy experiencing challenging theater. The more positive reviews underlined as much. But this might not be enough as a transgressive bodily representation might be intrinsically designed to fail to find a larger audience - if transgression is possible at all. ${ }^{16}$ Others, like the Wooster Group, have experienced a similar struggle to maintain the audience's interest. At this stage, it is premature to assess accurately the meaning of lower turnout and decide whether the American experimental trend to which the Big Art Group's political and artistic concerns belong is a failure or a success. What can be said is that, through collage and fragmentation, Manson and Nelson strenuously explore the materiality and immateriality of theater in order to see through the haze of technological immediacy and normative deceptions. The multiple queer identifications through a multimedia camp style provide leads to figure out how the corporeal is redefined by the stage today. By blurring a univocal perception, the Big Art Group circulates the multiple meanings that shape the body and make it, more than ever, a fluid concept. Hence, at best, the Big Art Group's queer and technological perspectives help us experience the mutations of our digital age, rethink our relationship to the codes of representation, and initiate a corporeal political resistance.

\section{BIBLIOGRAPHY}

Aronson, Arnold. American Avant-Garde Theatre: A History. London \& New York: Routledge, 2000.

Auslander, Philip. Liveness, Performance in a Mediatized Culture. New York \& London: Routledge, 1999. 
Avila, Robert. "Way Out East." San Francisco Bay Guardian Online 17 January 2012. http:// sfbgarchive.48hills.org/sfbgarchive/2012/01/17/way-out-east/

Bernard, Michel. Le Corps. Paris: Seuil, 1995.

Brecht, Stefan. Queer Theatre. Berlin: Suhrkamp, 1978.

Butler, Judith. Bodies that Matter: On the Discursive Limits of 'Sex.' New York \& London: Routledge, 1993.

Callens, Johan. “The Wooster Group's Hamlet, According to the True, Original Copies.” Theatre Journal 61.4 (December 2009): 539-561. https://muse.jhu.edu/article/380361

Duverger, Sylvie, and Thierry Hocquet. "Le corps hors de lui" [Interview of Judith Butler]. In “Body Building: L'évolution des corps.” Critique 764-765 (2011/1): 73-86. DOI: 10.3917/criti. 764.0073

Féral, Josette. "Pour une poétique de la performativité : le théâtre performatif." Théorie et pratique du théâtre : Au-delà des limites. Montpellier: Entretemps, 2011. 107-138.

Foultier, Anna Petronella. "Toward a Phenomenological Account of Dancing Body: Merleau-Ponty and the Corporeal Schema." In Material of Movement and Thought: Reflections on the Dancer's Practice and Corporeality. Eds. Anna Petronella Foultier and Cecilia Roos. Stockholm: Firework Edition, 2013. 51-71.

Gallagher-Ross, Jacob. "Image Eater: Big Art Group Brings the Noise.” The Drama Review 54:4 (T208) (Winter 2010): 54-80. DOI: 10.1162/DRAM_a_00024

Kaufman, David. Ridiculous! The Theatrical Life and Times of Charles Ludlam. New York: Applause, 2002.

Landrin, Ophélie. “A New York, le Big Art Group est encore absolumment underground, Caden Manson.” UBU Scènes d'Europe 40-41 (April 2007): 91-94.

Lehmann, Hans-Thies. Le Théâtre postdramatique. Paris: L’Arche, [1999] 2002.

Lemoine, Xavier. "Spirales baroques : quand le Wooster Group tourne et retourne Hamlet." In Théâtre Anglophone. De Shakespeare à Sarah Kane : l'envers du décor. Eds. Coulon and March. Montpellier: L'Entretemps, 2008. 61-73.

Ludlam, Charles. The Complete Plays of Charles Ludlam. New York: Harper \& Row, 1989.

Manson, Caden, and Jemma Nelson, eds. Contemporary Performance Almanac 2013. New York: Contemporary Performance, 2014.

Manson, Caden. Unpublished interview with Xavier Lemoine, December 2008.

Manson, Caden Unpublished interview with Xavier Lemoine, May 2015.

Merleau-Ponty, Maurice. Le visible et l'invisible. Paris: Gallimard, [1964] 2015.

Munoz, Jose E. Disidentifications: Queers of Color and the Performance of Politics. Minneapolis \& London: U. of Minnesota P., 1999.

Newton, Esther. Mother Camp: Female Impersonation in America. Chicago and London: U. of Chicago P., [1972] 1979.

Parker-Starbuck, Jennifer. Cyborg Theatre: Corporeal/Technological Intersections in Multimedia Performance (Performance Interventions). New York: Palgrave Macmillan, 2011.

Phelan, Peggy. Mourning Sex: Performing Public Memories. New York and London: Routledge, 1997. 
Meyer, Moe, ed. The Politics and Poetics of Camp. New York \& London: Routledge, 1994.

Rothkin, Andrew. "Broke House" [review]. nytheatre.com. 6 April 2012. [archived: https:// web.archive.org/web/20130807092253/http://www.nytheatre.com/Review/andrewrothkin-2012-4-6-broke-house]

Shank, Theodore. Beyond the Boundaries: American Alternative Theatre. Ann Arbor: U. of Michigan P., [1986] 2002.

Schneider, Rebecca. The Explicit Body in Performance. London and New York: Routledge, 1997.

Sontag, Susan. "Notes on 'Camp'." Against Interpretation and Other Essays. New York: Picador, 1961. 275-293.

\section{NOTES}

1. See Aronson (2000) on American context of performance, especially 144-204. Or the revised edition of Beyond the Boundaries: American Alternative Theatre by Theodore Shank (2002). For multimedia see, for instance, Parker-Starbuck (2011).

2. (Author's translation.) We prefer this term to the widespread "postdramatic" label that fails to clearly acknowledge these tensions; see Lehmann (2002). Manson and Nelson's work on producing a reference book on performance art worldwide illustrates their active participation in this art scene.

3. See https://vimeo.com/118450251 for clips of their previous shows and examples of their Real time technique.

4. We have in mind the questions raised by the reflections on the body developed by MerleauPonty's phenomenology. See Bernard (1995: 17-71) and Foultier (2013).

5. See Merleau-Ponty, Le visible et l'invisible, Paris: Gallimard, 1964, 172-204, quoted in Bernard (1995: 53). The notion of "reversibility" that allows a "metamorphosis" of perception seems the most apt here to account for the experience of the body on stage. See Auslander (1999).

6. “Big Art Group's “Broke House” at Abron's Arts.” Posted on 12 April 2012 by Jeremy M. Barker; https://www.culturebot.org/2012/04/13035/big-art-groups-broke-house-at-abrons-arts/.

7. "In the RTF technique of House of No More, for example, the stage represents and maps several different spaces: what we refer to as Work, Constructed, and Hybrid Spaces." (Manson and Nelson, 2015).

8. Gordon Matta-Clark 1970s "anarchitecture" clearly relates to the construction/destruction of the house.

9. It is worth noticing that Nelson strongly opposes Sontag's definition of camp.

10. The script of the play is in Ludlam (1989: 221-251). For a detailed account of the production of the play see Kaufman (2002: 185-194). For a queer reading of camp see Meyer (1994: 1-22), and especially on Camille (Meyer 1994: 137-141).

11. If we agree with Sontag's idea of camp as based on artifice: "Indeed the essence of Camp is its love of the unnatural: of artifice and exaggeration" (Sontag 275). A similar idea of the completion of the drag queen's becoming thanks to film is argued by Butler about the documentary film Paris Is Burning (Butler 135).

12. Stefan Brecht wrote about "The sheer beauty of junk" when he described Smith's performances in June 1970 ("Withdrawal from Orchid Lagoon," June 21) and January 1971 ("Claptailism of Paloma Christmas Spectacle," January 2; "Gas Station of the Cross Religious," January 30) underlined this notion of trash (Brecht 10).

13. See Butler explained in an interview “'queer' is the name of a political movement against identity politics" (Duverger 86; translation ours). 
14. This could be connected to Smith's criticism of the capitalist system and especially its inability to provide food and shelter to the people. Smith used to talk about "landlordism."

15. Smith performed many shows in the East Village just above First Avenue, not far from the Lower East Side in Manhattan where Broke House was performed, precisely at 466 Grand Street (cf. posters in Hoberman \& Leffingwell 9). This geography included the network of queer performance spaces on East $4^{\text {th }}$ Street in the 1980s with the WOW Café. Today, Bushwick in Brooklyn seems to be the latest neighborhood where queer venues have mushroomed.

16. See Schneider's discussion of transgression that takes to task the claim that the appropriating power of late capitalism makes transgression impossible (Schneider 3-4).

\section{ABSTRACTS}

The Big Art Group has joined the New York performance scene since 1999, exploring primarily with the effects of multimedia on stage. They developed acting techniques combined with video, called Real Time Film, offering fresh questions about performing in the $21^{\text {st }}$ century. In Broke House (2012), Jemma Nelson, Caden Manson and their actors continue the exploration on the meaning of the body by mixing two plots and modes of representation. The show, based on improvisations around Chekhov's Three Sisters and a documentary film, among other things, derails normative codes of reception and helps us question the instability of the meaning of the body, which is criss-crossed by shifting epistemologies. The result is a performance that stages fluxes of non-normative desires constantly oscillating between embodied subjectivities and evanescent illusions of the body. The powerful visual quality of the play, enhanced by huge screens, clashes with the makeshift scenery and hyperreal acting in order to reveal the violence that underpins the redefinition of the body on stage in our neoliberal, digital age. By looking closely at the structure of the piece and its scenography, I chart how the flesh and the digital interact through cinematic and theatrical tricks. Further, I highlight how the Group delineates a corporeality embroiled in social, esthetic, and phantasmatic structures and patterns by arguing that they deploy new forms of queer representations. Ultimately, I want to suggest how a phenomenology of the technological body helps grasp how the theatrical corporeality becomes illusory and elusive through queer technology and queer camp practices.

Depuis 1999, la troupe newyorkaise Big Art Group explore principalement l'impact de la performance multimédia sur la scène théâtrale. Elle a plus particulièrement développé un travail sur le jeu de l'acteur et son rapport à la vidéo grâce à leur technique du Tournage en Temps Réel, en posant de nouvelles questions sur la pratique des arts de la scène au XXIème siècle. Dans Broke House (2012), Jemma Nelson, Caden Manson et leurs comédiens prolongent leur exploration des significations du corps en mêlant deux intrigues et deux modes de représentation. Ce spectacle, créé à partir d'improvisations autour des Trois sœurs de Tchekhov et d'un film documentaire, fausse les codes normatifs de la réception et nous permet de nous interroger sur l'instabilité des significations d'un corps traversé par des mutations épistémologiques. Il en résulte un travail qui met en scène les flux de désirs non-normatifs oscillant entre l'incarnation de subjectivités multiples et d'une corporalité illusoire et évanescente. La puissante qualité visuelle de cette pièce, magnifiée par les gigantesques écrans sur scène, se heurte à un décor fait de bric et de broc et au jeu hyperréaliste des acteurs afin de mettre au jour la violence implicite qui préside à la redéfinition du corps scénique à l'ère digitale et néolibérale. Ainsi en m'intéressant plus 
particulièrement à la structure et à la scénographie de ce spectacle, je tente de cartographier la façon dont la chair et le numérique interagissent à travers des procédés cinématographiques et théâtraux. En outre, je cherche à éclairer dans quelle mesure la troupe dessine les contours d'une corporalité embranchée dans les écheveaux sociaux, esthétiques et fantasmatiques grâce au déploiement des nouvelles représentations queer. En dernier ressort, je tiens à suggérer comment une phénoménologie du corps technologisé aide à saisir la façon dont la corporéité scénique devient illusoire et insaisissable à travers une pratique camp et technologique du queer.

\section{INDEX}

Keywords: performance, United States, multimedia, queer, screen, technology, representation, camp, theatre, cultural studies, body, Big Art Group, phenomenology

Mots-clés: performance, États-Unis, multimedia, queer, écran, technologie, représentation, camp, théâtre, études culturelles, corps, Big Art Group, phénoménologie

\section{AUTHOR}

\section{XAVIER LEMOINE}

Xavier Lemoine is an Associate Professor at the University of Paris-Est Marne-la-Vallée where he teaches American studies. He wrote his PhD dissertation on Queer Theater in the United States. $\mathrm{He}$ is a member of the research group LISAA. His research focuses on postmodern identities and representations (sexuality, gender, race, class, multimedia, hybridity, etc.) mainly in contemporary theater and performance. He worked as an assistant director (Paris theater schools and Théâtre du Soleil) and translator (Baltimore Waltz by P. Vogel). His latest publications include articles on Tennessee Williams (in Tennessee Williams and Europe, Intercultural Encounters, Transatlantic Exchanges. Ed. John S. Bak. Amsterdam \& New York: Rodopi, 2014; Miranda 8, 2013), underground cinema (Cinémaction, 154, 2015). He also co-edited Understanding Blackness Through Performance: Contemporary Arts and the Representation of Identity with Anne Crémieux and Jean-Paul Rocchi (New York: Palgrave Macmillan, 2013). He is currently furthering work on multimedia performance and queer African-American ethnographic performances by E.P. Johnson. Contact: xavier.lemoine [at] u-pem.fr. 